Pesq. Vet. Bras. 37(11):1327-1330, novembro 2017 DOI: $10.1590 / \mathrm{S} 0100-736 \mathrm{X} 2017001100021$

\title{
Extraintestinal isosporoid coccidian causing atoxoplasmosis in captive green-winged saltators: clinical and hematological features $^{1}$
}

\author{
Sabrina D.E. Campos²*, Camila S.C. Machado², Tatiana V.T. de Souza², \\ Renan C. Cevarolli ${ }^{3}$ and Nádia R.P. Almosny ${ }^{2}$
}

\begin{abstract}
Campos S.D.E., Machado C.S.C., Souza T.V.T., Cevarolli R.C. \& Almosny N.R.P. 2017. Extraintestinal isosporoid coccidian causing atoxoplasmosis in captive greenwinged saltators: clinical and hematological features. Pesquisa Veterinária Brasileira 37(11):1327-1330. Departamento de Patologia e Clínica Veterinária, Universidade Federal Fluminense, Rua Vital Brazil Filho 64, Santa Rosa, Niterói, RJ 24230-340, Brazil. E-mail: s.destri@gmail.com

Populations of green-winged saltators, Saltator similis, are decreasing especially because of illegal trade and infectious diseases. We describe natural cases of an extraintestinal isosporoid coccidian in caged $S$. similis, and suggest the need of preventive measures in handling these birds. Nonspecific clinical signs were seen in all of them, however, intracytoplasmic Atoxoplasma sp. was found in peripheral blood, reinforcing the idea of systemic isosporosis. Leukocytosis with high number of heterophils and monocytes suggested that atoxoplasmosis in green-winged saltators can progress as an acute disease. The birds showed clinical improvement after treatment. Handling recommendations were proposed to upgrade hygienic conditions of the facilities. We concluded that nonspecific symptoms and an acute inflammatory process can be associated with atoxoplasmosis in young S. similis. We emphasize the importance of blood smear to detect merozoites.
\end{abstract}

INDEX TERMS: Coccidia, atoxoplasmosis, green-winged saltators, Saltator similis, systemic isosporosis, hematology, confinement.

RESUMO.- [Coccidiose extraintestinal causando atoxoplasmose em trinca-ferros de cativeiro: aspectos clínicos e hematológicos.] As populações de trinca-ferro, Saltator similis, estão declinando especialmente em função do comércio illegal e das doenças infecciosas. Descrevem-se casos naturais de coccidiose extraintestinal em $S$. similis de cativeiro, sugerindo a necessidade de medidas preventivas no manejo desses animais. Sinais clínicos inespecíficos foram observados em todos os animais, contudo, formas intracitoplasmáticas de Atoxoplasma sp. foram vistas no sangue periférico, reforçando a ideia de isosporose sistêmica. Leucocitose com aumento de heterófilos e monócitos sugeriram que a atoxoplasmose em trinca-ferro pode progredir

\footnotetext{
${ }^{1}$ Received on January 24, 2017.

Accepted for publication on June 20, 2017.

${ }^{2}$ Departamento de Patologia e Clínica Veterinária, Universidade Federal Fluminense (UFF), Rua Vital Brazil Filho 64, Santa Rosa, Niterói, RJ 24230340, Brazil. *Corresponding author: s.destri@gmail.com

${ }^{3}$ Hamadulu Cuidados Veterinários, Avenida das Américas 12300, Loja 111, Recreio dos Bandeirantes, Rio de Janeiro, RJ 22790-702, Brazil.
}

como uma doença aguda. As aves apresentaram melhora clínica após tratamento. Recomendações de manejo foram propostas a fim de melhorar as condições higiênicas das instalações das aves. Concluiu-se que sinais inespecíficos e processo inflamatório agudo podem ser associados com a atoxoplasmose em $S$. similis jovens. Enfatizamos a importância da avaliação do esfregaço sanguíneo para detector os merozoítos.

TERMOS DE INDEXAÇÃO: Coccidiose extraintestinal, atoxoplasmose, trinca-ferros, Saltator similis, isosporose sistêmica, hematologia, confinamento.

\section{INTRODUCTION}

Coccidians, including protozoa of the genus Isospora are common parasites of birds (Greiner 2009, Brown et al. 2010). However, one of the most interesting manifestations of coccidian infection in passerine birds is the development of extraintestinal stages of systemic isosporosis, traditionally known as atoxoplasmosis (Levine 1982, McNamee et al. 1995, Adkesson et al. 2005, Cushing et al. 2011). 
The disease syndrome atoxoplasmosis is surrounded by unanswered gaps about its pathogenesis and classification of the causative agent (Schrenzel et al. 2005, Cushing et al. 2011).

The genus Atoxoplasma was proposed to describe the protozoa found inside avian leukocytes since there are Isospora species that are not capable to parasitize mononuclear cells. So it is further considered that the name Atoxoplasma may be helpful for separating the organisms in blood from those that develop only in intestinal cells (Isospora sp.).

The parasite is transmitted via the faecal-oral route and birds become infected after ingesting sporulated oocysts (Levine 1982, Adkesson et al. 2005). Merogony occurs in both intestinal and lymphoid-macrophage cells, resulting in the presence of protozoa in the mononuclear leukocytes of the peripheral blood (Adkesson et al. 2005). Traditional methods for diagnosis of atoxoplasmosis are based on finding the parasite inside mononuclear cells in blood films or buffy coats, organ impression smears, and liver biopsies (Adkesson et al. 2005, Maslin \& Latimer 2009, Cushing et al. 2011).

Infection is possibly endemic among free-ranging birds with fatal disease occurring under the influence of stress or immunosuppression, notably in captive and young birds (Gill \& Paperna 2008, Maslin \& Latimer 2009, Cushing et al. 2011). Studies suggested that extraintestinal stages of coccidians are highly pathogenic to young birds with mortalities reaching up to $80 \%$ (Adkesson et al. 2005, Barbon et al. 2013, Jamriška et al. 2013). Effective treatment is not completely clear (Norton et al. 2003, Jamriška et al. 2013).

The green-winged saltator, Saltator similis, is a Brazilian cardinal passerine, highly appreciated by the song, but whose populations have been decimated by illegal trade for confinement (Coelho et al. 2013, IUCN 2015). Considering that prevalence and definitive treatment are still not fully elucidated, and the possibility of high rate of mortality, the aim of this study was to describe clinical and hematological abnormalities associated with atoxoplasmosis in captive $S$. similis from Brazil and suggest the need of preventive measures in handling these animals.

\section{MATERIALS AND METHODS}

Three sick birds (two female and one male) from legal private breeders, about 8 months old, were sent to one veterinary care center. The owners reported that the birds were kept in individual cages in an enclosed space along with numerous cages and different species of birds, such as canaries and psittacine. They were subject to a common routine management of handling and cleaning.

Blood samples were obtained from the jugular vein for hematological tests. Whole blood was placed in ethylenediaminetetraacetic acid (EDTA) tubes. Microhematocrit tubes were filled and centrifuged to determine packed cell volume. Red blood cell and white blood cell (WBC) counts were carried out in Neubauer counting chambers. Mean Corpuscular Volume was calculated following the same method used for mammals. Differential WBC counts in blood films were performed based on the count of 100 WBC under 1000x magnification. Samples from Saltator similis without clinical signs were subsequently obtained for evaluation of blood smears.
Reference values for $S$. similis were not found. The results were then compared with another bird of the same family, turquoise tanager (Passeriformes: Thraupidae), obtained from the International Species Information System-ISIS (www.isis.org).

Toltrazuril in drinking water for 14 days was elected to treat these birds. During the treatment, IM enrofloxacin was added.

\section{RESULTS}

All the birds presented nonspecific clinical signs of sudden onset including lethargy, anorexia, weight loss, pectoral muscle reduction, beak depigmentation, ruffled feathers, diarrhea and severe depression.

Round to oval intracytoplasmic merozoites displaying purple-red center were found inside lymphocytes of the three birds (Fig.1), confirming the systemic isosporosis (atoxoplasmosis). Merozoites were widespread in the blood films. Blood smears of healthy Saltator similis were negative for the presence of merozoites in circulating leukocytes.

Hematological findings are presented in table1. None of the birds in this study had anemia. All animals presented leukocytosis with lymphocytosis and high number of heterophils. Basophil counts were lower than the reference values for all birds. Animal number one also showed immature heterophil and high monocyte and eosinophil counts, while the animal number two showed large and vacuolated thrombocytes, and animal number three showed toxic heterophils.

All animals were clinically healthy at the end of a 14 days treatment with toltrazuril. Blood and fecal samples were evaluated after clinical improvement, which showed no evidence of coccidia.

Handling recommendations were proposed aiming the improvement of hygienic conditions of the facilities and educating the owners about the risk of fecal-oral transmission of coccidian and other diseases. These recommendations included: cages with a wire bottom, elevated feed

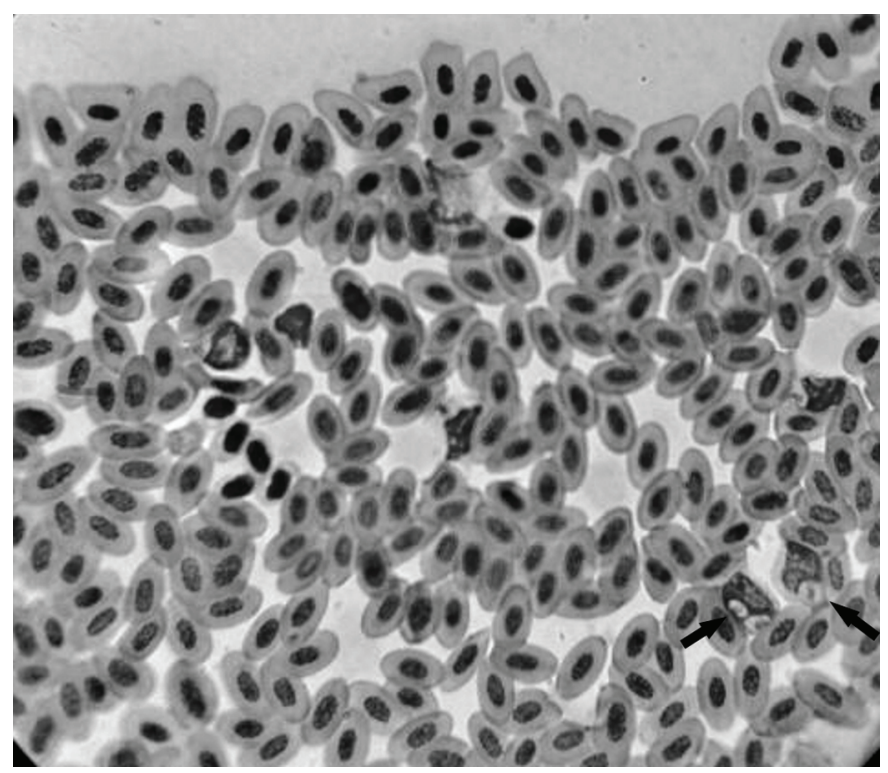

Fig.1. Blood smear of green-winged saltator, Saltator similis, showing the presence of merozoites of Atoxoplasma (arrow) in circulating lymphocytes. Personal archive. Diff-quik stain. Obj.100x. 
Table 1. Mean \pm standard deviation for hematologic results in green-winged saltators, Saltator similis, diagnosed with systemic isosporosis (atoxoplasmosis)

\begin{tabular}{lccccc}
\hline Variable & Bird \#1 & Bird \#2 & Bird \#3 & $\begin{array}{c}\text { Mean } \pm \text { standard } \\
\text { deviation }\end{array}$ & $\begin{array}{c}\text { Reference } \\
\text { Values (ISIS) }\end{array}$ \\
\hline Red blood cell $\left(\mathrm{x} 10^{6} / \mu \mathrm{L}\right)$ & 4.12 & 4.93 & 4.55 & $4.53 \pm 0.41$ & $4.47 \pm 0.53$ \\
Hemoglobin $(\mathrm{g} / \mathrm{dL})$ & 14.7 & 15.3 & 15.3 & $15.10 \pm 0.35$ & 15.3 \\
Packed cell volume (\%) & 50 & 55 & 55 & $53.33 \pm 2.89$ & $49.8 \pm 6.3$ \\
Mean corpuscular volume (fL) & 121.4 & 111.8 & 120.9 & $118.03 \pm 5.40$ & $108.0 \pm 25.6$ \\
Mean corpuscular hemoglobin & 29.4 & 27.9 & 27.9 & $28.40 \pm 0.87$ & 34.8 \\
concentration $(\%)$ & & & & & \\
White blood cell $\left(10^{3} / \mu \mathrm{L}\right)$ & 45000 & 21400 & 14000 & $26800 \pm 16190.12$ & $7768 \pm 5430$ \\
Basophils $(/ \mu \mathrm{L})$ & 0 & 0 & 0 & 0 & $1904 \pm 1004$ \\
Eosinophils $(/ \mu \mathrm{L})$ & 900 & 0 & 0 & $300 \pm 519.62$ & $321 \pm 380$ \\
Heterophil bands $(/ \mu \mathrm{L})$ & 1800 & 0 & 0 & $600 \pm 1039.23$ & - \\
Heterophils $(/ \mu \mathrm{L})$ & 12600 & 7918 & 6160 & $8892.67 \pm 3328.80$ & $2003 \pm 1789$ \\
Lymphocytes $(/ \mu \mathrm{L})$ & 23400 & 11770 & 6720 & $13963.33 \pm 8553.57$ & $3535 \pm 2647$ \\
Monocytes $(/ \mu \mathrm{L})$ & 6300 & 1712 & 1120 & $3044 \pm 2835.27$ & $1191 \pm 1592$
\end{tabular}

stations, periodic cleaning with sodium hypochlorite, and facilities ventilation.

\section{DISCUSSION}

Clinical signs presented by infected Saltator similis birds are usually non-specific. Thus, atoxoplasmosis is primarily indicated by the presence of endogenous stages in blood cells (McNamee et al. 1995, Martinez \& Muñoz 1998, Sánchez-Cordón et al. 2007, Maslin \& Latimer 2009, Jamriška et al. 2013). However, the severity of symptoms can compromise the survival of birds, leading to the "going light" syndrome (diarrhea, emaciation, and death) (Gill \& Paperna 2008). In our case, none of the animals died, suggesting the importance of early diagnosis and treatment.

Leukocytosis with high number of heterophils, immature heterophils and monocytosis suggested the presence of a local or general inflammatory process due to acute disease. Lymphocytosis and morphological changes of thrombocytes could be explained by the result of antigenic stimulation due to merogony, and the presence of toxic heterophils suggested that atoxoplasmosis behaves as a severe systemic illness possibly associated with secondary opportunistic diseases. Basophils contain heparin and histamine, which promote blood flow to tissues. Therefore, they can assist in inflammatory processes, and its reduction could indicate an unfavorable prognosis if the birds were not treated. However, our results showed that treatment with toltrazuril combined with enrofloxacin promoted improvement in clinical status and survival of infected birds. Similarly, Jamriška et al. (2013) concluded that toltrazuril is effective against atoxoplasmosis.

Infected adults are generally asymptomatic. Therefore, transmission of coccidia from them to juveniles after egg-laying period should be a concern (Maslin \& Latimer 2009). We believe that this was the source of infection in our study. It is possible that captivity, inadequate hygiene, and overcrowding have favored the contamination of the animals and contributed to the worsening of their state of health. Coelho et al. (2013) proposed protocols based on the periodicity of oocyst shedding as a form of early identification of coccidiosis in triage centers.

We strongly recommend a routine of regular fecal and blood examinations, segregation of positive birds for treat- ment and incorporation of screening tests into quarantine protocols, since the disease may be underdiagnosed. We emphasize the importance of early laboratory diagnosis and the institution of proper treatment.

\section{CONCLUSION}

Our results showed that: (1) young Saltator similis may be susceptible to systemic isosporosis (atoxoplasmosis), (2) symptoms are usually nonspecific, (3) hematologic abnormalities suggest acute inflammatory disease with antigenic stimulation, (4) blood smear plays a key role in the detection of Atoxoplasma merozoites inside lymphocytes, (5) early diagnosis and proper treatment can enhance the survival of the birds.

\section{REFERENCES}

Adkesson M.J., Zdziarski J.M. \& Little S.E. 2005. Atoxoplasmosis in tanagers. J. Zoo Wildl. Med. 36(2):265-272.

Barbon A.R., Jamriška J. \& Lopéz J.F. 2013. Atoxoplasmosis in captive blue crowned laughing thrush (Dryonastes courtoisi) at Durrell Wildlife Conservation Trust. ICARE, Wiesbaden, Germany. 119p. Available in <https://www.researchgate.net/publication/261873236_BARBON_ AR_JAMRISKA_JJJ_F_LOPEZ_2013_Atoxoplasmosis_in_captive_blue_crowned_laughing_thrush_Dryonastes_courtoisi_at_Durrell_Wildlife_Conservation_Trust_ICARE_Wiesbaden_Germany_119>. Accessed on Aug. 31, 2016.

Brown M.A., Ball S.J. \& Snow K.R. 2010. Coccidian parasites of British wild birds. J. Nat. Hist. 44:2669-2691

Coelho C.D., Berto B.P., Neves D.M., Oliveira V.M., Flausino W. \& Lopes C.W.G. 2013. Oocyst shedding by green-winged-saltator (Saltator similis) in the diagnostic of coccidiosis and Isospora similisi n. sp. (Apicomplexa: Eimeriidae). Revta Bras. Parasitol. Vet. 22(1): 64-70.

Cushing T.L., Schat K.A., States S.L., Grodio J.L., O’Connell P.H. \& Buckles E.L. 2011. Characterization of the host response in systemic isosporosis (atoxoplasmosis) in a colony of captive American goldfinches (Spinus tristis) and house sparrows (Passer domesticus). Vet. Pathol. 48(5):985992.

Gill H. \& Paperna I. 2008. Proliferative visceral Isospora (atoxoplasmosis) with morbid impact on the Israeli sparrow Passer domesticus biblicus Hartert, 1904. Parasitol. Res. 103(3):493-499.

Greiner E.C. 2009. Isospora, Atoxoplasma, and Sarcocystis, p.108-119. In: Atkinson C.T., Thomas N.J. \& Hunter D.B. (Eds), Parasitic Diseases of Wild Birds. Wiley-Blackwell, New York.

IUCN 2015. The IUCN Red List of Threatened Species. Version 2015-4. Available in <www.iucnredlist.org> Accessed on Jun18, 2016. 
Jamriška J., Lavilla L.A., Thomasson A., Barbon A.R., Lopéz J.F. \& Modrý D. 2013. Treatment of atoxoplasmosis in the Blue-crowned Laughing Thrush (Dryonastes courtoisi). Avian Pathol. 42(6):569-571.

Levine N.D. 1982. The genus Atoxoplasma (Protozoa, Apicomplexa). J. Parasitol. 68:719-723.

Martinez F. \& Muñoz E. 1998. Atoxoplasma spp. in a hybrid passerine (Serinus canarius $\times$ Carduelis cannabina). Avian Pathol. 27:420-422.

Maslin W.R. \& Latimer K.S. 2009. Atoxoplasmosis in Canary Fledglings: Severe Lymphocytic Enteritis with Preferential Parasitism of B Lymphocytes. Avian Dis. 53(3):473-476.

McNamee P., Pennycott T. \& McConnell S. 1995. Clinical and pathological changes associated with atoxoplasma in a captive bullfinch (Pyrrhula pyrrhula). Vet. Rec. 136(9):221-222.
Norton T.L., Neiffer D.L., Seibels B., Benson K., McAloose D., Travis D., Greiner E., Latimer K., Little S.E., Zdziarski J.M., Schrenzel M., Rideout B., Vince M. \& Gentz N. 2003. Atoxoplasma medical protocols recommended by the passerine atoxoplasma working group. Eastern Regional AZA conference in Columbia. Available in <http://www.aazv.org/?545> Accessed on Aug. 31, 2016.

Sánchez-Cordón P.J., Gómez-Villamandos J.C., Gutiérrez J., Sierra M.A., Pedrera M. \& Bautista M.J. 2007. Atoxoplasma spp. infection in captive canaries (Serinus canaria). J. Vet. Med. A, Physiol. Pathol. Clin. Med. 54(1): 23-26.

Schrenzel M.D., Maalouf G.A., Gaffney P.M., Tokarz D., Keener L.L., McClure D., Griffey S., McAloose D. \& Rideout B.A. 2005. Molecular characterization of isosporoid coccidia (Isospora and Atoxoplasma spp.) in passerine birds. J. Parasitol. 91(3):635-647. 